Journal of Money and Economy

Vol. 15, No. 2, Spring 2020

pp. $199-220$

DOI:10.2952/jme.15.2.199

Original Research Article

\title{
Regulating Iranian Card Payments System as a Two- Sided Market
}

\author{
Hossein Aghaei* \\ Farhad Khodadad Kashi ${ }^{\ddagger}$ \\ Reza Talebloo ${ }^{\dagger}$
}

Received: 29 Apr $2020 \quad$ Approved: 28 Dec 2020

This paper examines the necessity of regulating the Iranian card payments system (SHAPARAK) based on the theory of two-sided markets. The expansion of the payment card system in recent years has arisen some questions regarding the role of all kinds of costs and expenses such as interchange fees, cardholder fees, merchant fees, and network externality in balancing the market. Since there is only an interchange fee in Iran, regulation of the card payments system is necessary to assess the variables affecting this system. The data used in this study consist of 1218 observations of 29 banks from March 2016 to August 2019. The econometric method for this purpose is the fixed effects panel data model.

The results indicate that the interchange fee has an essential role in balancing the Iranian card payment system market. Also, network externality makes the opportunity for balancing the market by decreasing the interchange fee and finally reducing transaction costs for acquirer banks. This policy can lower the interest rate of the bank loans because, in the Iranian card payment system, cardholders and merchants do not pay fees for transactions. So, banks try to attract clients for issuing cards and receive interchange fees as revenue to compensate for the payment network costs by the interest rate of loans. Overall, the results of the estimated model show that improving the card payments system in Iran should be regulated by related organizations.

Keywords: Payment Card System; Two-Sided Market; Regulation.

JEL Classification: L5, L82, L86

\section{Introduction}

The payment card is a platform-based system in which a platform provides financial services to cardholders and merchants (sellers). Platform-based activities are based on the literature of a two-sided market with network externalities. According to the Central Bank and the SHAPARAK system,

\footnotetext{
* Allameh Tabataba'i University, Tehran, Iran; h.aghaei2001@gmail.com

† Allameh Tabataba'i University, Tehran, Iran; talebloo.r@gmail.com (Corresponding Author)

† Department of Economics, Payame Noor University, Tehran, Iran; khodadad@ pnu.ac.ir
} 
from March 2016 to August 2019, the number of payment cards, POS devices, and the value of card transactions has increased by 5, 70, and 116\%, respectively. Also, 29 banks with 20,476 branches are active in Iran that all issue debit cards, POS, and ATM. The Iranian bank mainly provides debit cards, and the share of credit cards in total bankcards is less than $1 \%$. Regarding the significant volume of financial transactions in Iran through bank cards, the monopoly of this system in Iran, and its effects on social welfare, it is necessary to pay attention to the regulation of this market.

In general, the main features of Iran Payments Network are:

A. Issuer banks that provide payment cards should pay $250 \mathrm{Rls}$ to SHAPARAK for each transaction and 250 Rls to SHETAB network for each transaction.

B. Acquirer banks that accept transactions on merchants (sellers) on POS should pay $1 \%$ of the transaction value to issuer banks as interchange fees (IF), but the fee should be a maximum of 2500 Rls.

C. The Iranian cardholders do not pay fees for using debit cards, and merchants that accepted POS do not pay any fee to acquirer banks.

D. Iran has 29 governments, private and professional banks that open accounts for clients and issue payment cards for them.

Iran's payment card system is monopolistic, and SHAPARAK is the sole platform for card payment.

According to the above features and two-sided market theories, the main questions are two-fold:

1) The analysis of issuing card structure with emphasis on the effects of interchange fees on issuing cards and the role of antitrust organizations and regulators for balancing the two sides of the Iran payment card network

2) Surveying the effects of other elements such as network externality, bank size, and interest of bank loans (as revenue for issuer banks) on issuing payment cards.

Despite the expansion of the card payments system in Iran from 20 years ago, this issue has not been studied from the perspective of two-sided markets. As a result, the literature on the subject is very limited in Iranian economic studies, and only the studies conducted in other countries can be considered. Overall, studies in other countries show that card payments systems regulation can be effective in improving social welfare, reducing the cost of financial transactions, and improving the use of card payments systems. 


\section{Literature Review}

The literature of platform-based industries has mainly focused on Two-sided platforms (two-sided markets). In the considered systems, a platform serves two groups of agents so that the participation of (at least) one group increases the value of participating for the other group (that named 'indirect' network effect) Hunt, R. (2003). Examples are payment card networks, software, internet search engines, and Uber taxi (Snapp and TAPSI in Iran). The most theoretical studies in this field were conducted by Rochet and Tirole (2003), Armstrong (2006), and Caillaud and Jullien (2003), but the empirical studies are limited mainly due to the lack of reliable data. It has been argued that more empirical evidence on network industries is needed to test some theoretical predictions and to assist regulators and antitrust authorities in their supervision and monitoring of competitive and strategic trends in areas such as payment card markets (Rochet and Tirole 2003, 2004 and 2005).

The majority of card transactions take place at the point of sale (POS) and automated teller machines (ATMs), which depend on network externalities (Gowrisankaran and Stavins, 2004). The vertical organization of 'traditional' bank markets often causes payment cards to be treated by regulatory authorities. In general, a payment card has two principal characteristics:

1) They are organized as network systems, in which the adoption of cards depends on the adoption of POS terminals (merchant acceptance), and vice versa. For a given set of fees, a consumer is more likely to use a card if it is widely accepted by merchants, while merchants are more likely to accept a card which is used by many consumers (Armstrong, 2006).

2) Card services are organized as two-sided markets in which banks may act as issuers (providing payment cards) and acquirers (providing POS terminals to merchants). This structure implies the necessity of coordinating the transactions and prices of all banks acting as issuers and/or acquirers. Banks that are offering card services tend to be organized as networks. (Schmalensee, R., 2002).

Network associations usually demand that the bank acting as the acquirer for the merchant must pay an interchange fee to the issuing bank. Acquiring banks also charge merchants a fee, while cardholders usually pay an annual fee for the privilege. The so-called 'no surcharge' rule applied in most countries means they rarely pay any fees to merchants. Given this price structure, the market will be two-sided when prices and transactions on either side of the market (cardholders or merchants) significantly affect prices and transactions on both sides and not merely one of them (Rochet and Tirole, 2003). 
In recent years, card payments have received great attention from anticompetition authorities Katz, M.L. (2001). In this regard, anti-competition scrutiny has been concentrated on how banks set merchant and cardholder prices and the degree to which one side of the market (namely cardholders) may be "subsidized" by the other (merchants). Many anti-competition rulings and class action lawsuits against card associations worldwide have involved substantial changes in card pricing schemes in some countries (e.g., European countries and Australia) (European Commission, 2007). However, such regulatory changes have not always considered the network externalities and the price structure of payment card markets, and a considerable part of the antitrust analysis has been frequently undertaken using a standard vertically organized concept of the market. Consequently, anti-competition agencies have often issued resolutions that fail to take into account the two-sided nature of the market. There is limit empirical evidence to suggest that the payment card system as a two-way market, even to a limited extent, includes this rule. Humphrey and Berger (1990) and Humphrey and Pully (1997) have shown that efficient payment instrument pricing generates a greater use of the electronic payment since it is cheaper than a paper-based payment. Humphrey and Pully (1997) argue that the substitutability of credit cards for cash is dependent on both pricing and national cultural attitudes towards credit. It has also been observed that credit cards help to defer illiquid cardholder consumption (Chakravorti and T.TO, 2000; Chakravorti, 2003). In another study, Brito and Hartley (1995) demonstrated borrowing on credit cards may appear irrational, due to the higher interest rates usually paid. Such cards also provide liquidity services by allowing customers to avoid some of the opportunity costs of holding money.

\section{Theory of two-sided markets and the process of payment cards}

Rochet and Tirole (2003) initiated the theory of the two-sided markets, followed by their subsequent article in 2006. Other important studies about the early literature include Armstrong (2006), Caillaud and Jullien (2003), and Prager,Manusza, Kiser, and Borzekowski (2009). In a two-sided market, the platform gets together two separate groups of customers to generates value for each other. Generally, platform internalizes indirect network effects between two distinct side of the market.

In pricing of payment systems, theory of two-sided markets has central characteristic of the competition policy investigations some competition authorities investigated the setting of interchange fees by payment card 
networks. A bank receives interchange fees when consumers use bank card for purchases.

According to the theory of two-sided markets, platform coordinates the demands of two side of the market, customers, who need to attend in transaction to internalize the indirect network externalities between two sides of the market, platform resort to price and non-price strategies that are different from the firms that do not provide different dependent customer groups.

The platform has to choose both the price level and the price structure to hold on board two sides of the mark. The pricing structure that internalizes the indirect network externalities between two side of the market can be skewed. Means that one side being charged and the other being subsidized. An analysis that ignores the nature of this kind of markets might conclude that the platform is engaging in predatory pricing on one side of the market, and excessive pricing in the other side. It suggests that low prices on one side are being used to obtain, or maintain, market power on the other side (Knittel, C. and Stango V. 2003). Thus, for maximizing the profit, pricing the customers on either side is not based on a markup formula such as the Lerner condition, and price isn't equal marginal cost. Since two-sided platforms have to change one side of the market which has positive feedback effects on the other side of the market. Thus, these feedback effect is important to determine the overall effect of a price change on profits.

Regulators attention to incremental costs and followed this principle for surveying the price setting. However, this principle due to the presence of indirect network externalities and joint costs does not apply in two-sided markets. An alternative principle is the Ramsey pricing, which states that the price should be set so as the price-marginal cost margins are inversely related to the price elasticities of demand. Accordingly, from the side with inelastic demand, platform expect to capture more revenue. However, for analysis the two sided market the interdependence between the two sides has to be incorporated. Generally, the optimal pricing in two sided market should be based on some special featuers of this kind of markets such as demand-side considerations, indirect network effects and cost-side.

The main elements of the card payments system based on the theory of two-sided markets are as follows:

a. Issuer and acquirer banks: In the payment system platform, there are issuer banks that open accounts for clients and provide payment cards (debit or credit card). And acquirer banks that accept merchants 
(sellers) account to connect to POS for transferring money from buyer to merchant.

b. Two groups of customers: Payment system platform provides service simultaneously to two interdependent groups of customers, namely cardholders (buyers) and merchants (sellers). They need the intermediation of the platform to internalize the indirect network externalities across groups.

c. Network Effects across Groups (Network Externality): This means that the value that cardholders on one side realize from the platform increases with the number of merchants on the other side. According to this effect, the cardholder's demand to use payment cards depends on the number of merchants that accept cards for selling and viceversa.

d. Coordination: The platform must arrange the interdependent demands of the two side of the market customers. This arrangement requires some strategies such as price and non-price strategies that are very different from traditional firms Kaiser, U. and Wright, J. (2006). Price strategy is involved interchange fee that is paid by acquirer banks to issuer banks (Rochet and Tirole, J. 2002).

e. Non-Neutrality of the price structure: For internalizing the indirect network externalities across consumers the price structure can be very skewed. One side of the market may be charged almost nothing while the other side is responsible for most of the platform's revenues, and in most countries, merchants pay a cost to acquirer banks that named merchant discount. Regarding the importance of the price structure, the platform must design it to bring both sides on board.

f. Specific Competition Analysis: Payment system anti-competitive engagement in two-sided markets is same as a monopolistic firm in traditional markets. And their activities should be control by competition authorities according to the economics features and principles of two-sided platforms.

\subsection{Payment Card Process as a Two-Sided Market}

According to the above elements, in the payment card system, a two-sided market process of the payment is as follows: 


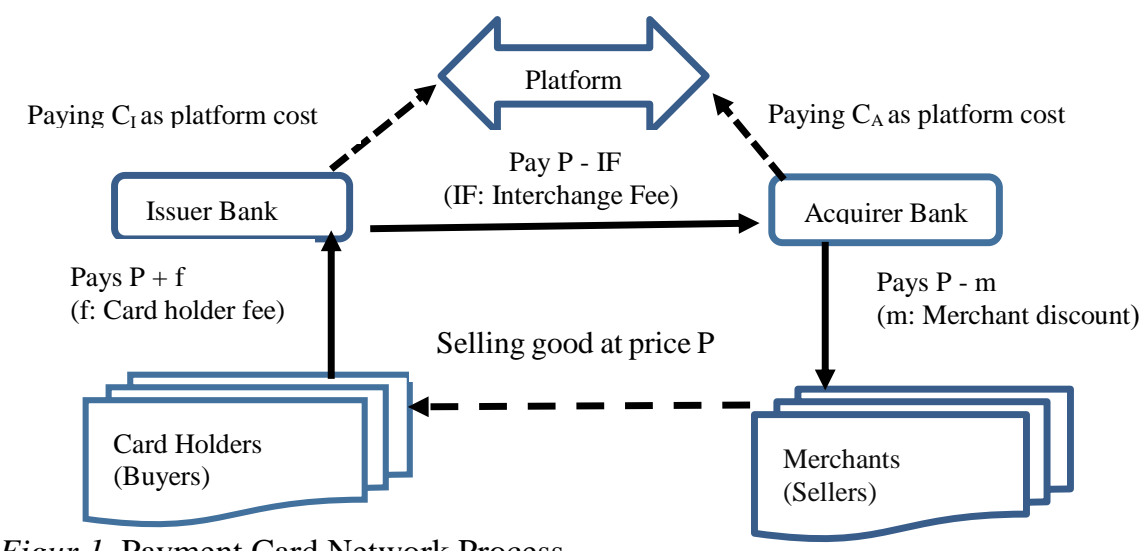

Figur 1. Payment Card Network Process.

According to Fig. 1, issuer and acquirer banks should pay platform costs $\mathrm{CI}$ and CA, respectively, for each card transaction. Also, the cardholder (buyer) for buying by payment card does not pay any fee to the merchant (seller) and only pays a fee (f) to the issuer bank for each transaction. Merchants should pay merchant discount $(\mathrm{m})$ to acquirer banks. The most important part of Fig. 1 is the interchange fee (IF) that the acquirer bank should pay to the issuer bank. The interchange fee is a specific percentage of the transaction value. IF is revenue for issuer banks and has a positive effect on issuing payment cards.

\subsection{Economic Principles and Profit Maximization of the card payments system}

According to the well-known Lerner condition, under perfect competition, the maximum profit is achieved by setting a price equal to the marginal cost. In other words, the price-marginal cost margin equals the inverse of the price elasticity of demand.

Thus, perfect competition is socially efficient. The size of the social deadweight loss is increasing in:

(i) The sensitivity of demand to price elasticity

(ii) Difference between price and marginal cost

If firms, discriminate price between different groups of consumers; i.e., they might tend to charge each group of consumers a different price. The group of consumers whose demand is more elastic will be charged at a lower price. Firms can increase their profits by charging each group of consumers at 
a different price. In two-sided platforms there are two different groups of consumers and platform sell two products.However, important differences between a two-sided platform and a one-sided price multi-product are as follow firm:

i) Indirect network externalities between groups of consumers

ii) joint costs for providing services to both types of consumers.It has several important implications that make the profit-maximizing pricing rule of a two-sided platform be different substantially from price (or marginal revenue) and become equal to the marginal cost.

In the presence of indirect network externalities, the marginal revenue of consumers has a direct and an indirect component.

Thus, for a two-sided platform the profit-maximizing condition is the marginal revenue equals marginal cost rule. Existence of indirect network externalities between consumers, effcts on the marginal revenue. The consumers with the highest level of gross group indirect network effects will be charged relatively less. In one side of the market consumers might pay the price below marginal cost. In contrast, consumers on the other side will be charged prices considerably above marginal cost, which generates most of the platform's revenues.

\subsubsection{Monopoly Platform}

When there is only one platform for the payment system, the profit not only depends on the total price but also depends on the distribution of price between two sides of the market (Tirole \& Rochet, 2003). The prices for maximizing profit of platform depend on demand and cost of each side of the market. Thus, using price equal marginal cost rule separately for each side is not suitable in this case, Baxter, W.F., (1983). On each side of the two-sided market, the profit maximizer price is probably higher or lower than the marginal cost. This subject will be surveyed for a private monopoly platform. The total amount of transactions in the payment platform is:

$\mathrm{T}\left(\mathrm{P}^{\mathrm{B}}, \mathrm{P}^{\mathrm{M}}\right)=\mathrm{D}^{\mathrm{B}}\left(\mathrm{P}^{\mathrm{B}}\right) * \mathrm{D}^{\mathrm{M}}\left(\mathrm{P}^{\mathrm{M}}\right)$

Where $\mathrm{P}^{\mathrm{B}}$ and $\mathrm{P}^{M}$ are the prices of cardholders and merchants and $\mathrm{D}^{\mathrm{B}}$ and $\mathrm{D}^{\mathrm{M}}$ are demands of cardholders and merchants, respectively. Decreasing the price for cardholders and merchants promote them for more using the platform. They are Quasi demand functions because the real demand depends on the services of the platform to each side, thus depends on cardholders and merchant's decisions. 
Monopolistic platform profit function with $\operatorname{cost} \mathrm{C}$ for each transaction will be

$\pi=\left(P^{B}+P^{M}-C\right) * D^{B}\left(P^{B}\right) * D^{M}\left(P^{M}\right)$

According to F.O.C conditions for maximizing equation (2) the demand function will be:

$\left(D^{B}\right)^{\prime} * D^{M}=D^{B} *\left(D^{M}\right)^{\prime}$

From equations (2) and (3) we can find the elasticity of buyer $\left(\varepsilon^{B}\right)$ and merchant $\left(\varepsilon^{M}\right)$ as equation (4)

$\varepsilon^{B}=-\frac{P^{B}\left(D^{B}\right) \prime}{D^{B}} \quad$ and $\quad \varepsilon^{M}=-\frac{P^{M}\left(D^{M}\right) \prime}{D^{M}}$

According to equation (4) we can find the condition of profit maximization of monopolistic platform

$P^{B}+P^{M}-C=\frac{P^{B}}{\varepsilon^{B}}=\frac{P^{M}}{\varepsilon^{M}}$

Total price $(P)$ equal $P^{B}+P^{M}$ and for monopoly platform, we have the bellow equation

$P=\frac{\varepsilon}{\varepsilon-1} C$

That $\varepsilon=\varepsilon^{B}+\varepsilon^{M}>1$

The important note in two-sided markets and also card payments is equation (7)

$P^{B}+P^{M}-C=\frac{P^{B}}{\varepsilon^{B}}=\frac{P^{M}}{\varepsilon^{M}}$

According to equation (7) we can calculate the price of each side of the market as follows

$P^{B}=\frac{\varepsilon^{B}}{\varepsilon} P=\frac{\varepsilon^{B}}{\varepsilon-1} C$

And 
$P^{M}=\frac{\varepsilon^{M}}{\varepsilon} P=\frac{\varepsilon^{M}}{\varepsilon-1} C$

Based on the above explanations in monopoly platforms of payment cards, profit maximization depends on Interchange Fee (IF) as the platform's total Price (P). Platforms should distribute interchange fees between cardholders and merchants according to their Price elasticity of each side of the market.

\subsubsection{Platforms Competition}

When there are many platforms in a two-sided market (e.g., many platforms for payment cards such as Visa card and Master card), the cardholder (buyer) can buy from one or more platforms. When buyers use only one platform, this situation is "single homing," and when using more than one platform, this situation is "multi-homing." For antitrust organizations and regulators, there is an important question: "What is the effect of decreasing competition between platforms on prices of each side of the market?" To answer this question, Wright (2005) provided a general model of platform completion in a two-sided market that surveys the effect of multi-homing on the market price and the demand on one side of the market (Wright, 2004). Suppose two platforms compete in the payment cards market. Note that the cardholders and merchants are heterogeneous, and their benefits according to their information from the market are different. Moreover, they can use at least one of the platforms for the transaction.

If the benefits of buyers and sellers on platform $i$ are $b_{i}^{B}$ and $b_{i}^{M}$, respectively, and the cost of the transaction with the platform for them is $P_{i}^{B}$ and $P_{i}^{M}$, the condition for using the platform $i$ for the buyer is:

$b_{i}^{B} \geq P_{i}^{B}$

This condition is true for using platform $j$, but the buyer will choose the platform $j$ if

$b_{j}^{B}-P_{j}^{B}>b_{i}^{B}-P_{i}^{B}$

From Eq. (14), it is inferred that if the net benefit of the buyer in a transaction with platform $j$ is more than the net benefit of a transaction with platform $i$, the buyer will choose platform $j$ for the transaction. Same as the above explanation for a merchant (seller) with the benefit $b_{i}^{M}$, the condition for using the platform $i$ for the buyer is: 
$b_{i}^{M} \geq P_{i}^{M}$

Merchant will select platform $j$ for a transaction if

$P_{j}^{M}<P_{i}^{M}$

In a multi-homing situation, buyers and merchants can transact on both platforms $i$ and $j$; however, one can state which platform will be chosen. In case merchants can use both platforms, buyers will compare the net benefit of the transaction on each platform (Ausubel, L, 1991). For example, if the net benefit of platform $j$ is more than the platform $i$, they will select platform $j$ for the transaction. In other words, situation platform $j$ will be used for transactions by buyers.

$b_{j}^{B}-P_{j}^{B}>b_{i}^{B}-P_{i}^{B}$

Comparing the two platforms buyer, the Quasi-demand function will be as follows. The right part of the Eq. (16) is the probability of selecting platform $i$.

$D_{i}^{B}=D_{i}^{B}\left(P_{i}^{B}\right)=\operatorname{Pr}\left(b_{i}^{B}-P_{i}^{B}>0\right)$

$D_{i}^{B}$ is the demand function of buyers that like buy from the merchants that use platform $i$. Also, we can write a demand function for the buyers that like to buy from the merchants that use both platforms $i$ and $j$ (multi-Homer merchants) as follows

$d_{i}^{B}\left(P_{i}^{B}, P_{\mathrm{j}}^{B}\right)=\operatorname{Pr}\left[b_{i}^{B}-P_{i}^{B}>\max \left(0, b_{j}^{B}-P_{j}^{B}\right)\right]$

This demand functions justify the condition (20)

$d_{i}^{B} \leq D_{i}^{B} \leq d_{i}^{B}+d_{j}^{B}$

If the distribution of $\left(b_{i}^{B} g b_{\mathrm{j}}^{B}\right)$ be symmetric then they will have symmetric demand equations as follow

$D_{i}^{B}\left(P^{B}\right)=D_{\mathrm{j}}^{B}\left(P^{B}\right) \equiv \widehat{D}^{B}\left(P^{B}\right)$

$d_{i}^{B}\left(P_{i}^{B}, P_{\mathrm{j}}^{B}\right) \equiv d_{\mathrm{j}}^{B}\left(P_{\mathrm{j}}^{B}, P_{i}^{B}\right)$

Where $P_{i}^{B}=P_{\mathrm{j}}^{B}=P^{B}$ and we have 
$d^{B}\left(P^{B}\right) \equiv d_{i}^{B}\left(P^{B}, P^{B}\right)$

If the prices are symmetric $P_{i}^{B}=P_{j}^{B}=P^{B}$ and $P_{i}^{M}=P_{\mathrm{j}}^{M}=P^{M}$ and there is a merchant with the benefit $b^{M}$ that work with two platforms $i$ and $j$ and $b^{M} \geq P^{M}$ Then the total amount of transactions on each of the platforms will be

$Q=d^{B}\left(P^{B}\right) * D^{M}\left(P^{M}\right)$

\section{The Model/Methodology}

\subsection{Statistical Population and Data}

The statistical population of this paper includes 29 government and private banks of Iran accepted by the Central Bank. Also, data related to card payment were gathered from monthly data of the Iranian Central Bank (CBI) and Iranian electronic payment network (SHAPARAK) from March 2016 to August 2019.

\subsection{The Model}

This paper adopts the theoretical model of two-sided markets constructed by Armstrong (2006), Carbó-Valverde, Humphrey, \& Zegarra (2009), Brito and Hartley (1995). They emphasize the interchange fee and network externality to describe the payment card markets. According to profit maximization in monopoly platforms at two-sided markets, for balancing the card payment system, the platform determines the interchange fee. It distributes this price between two sides of the market based on the elasticity of each side of the market. Iran's card payment system has a monopoly platform (i.e., SHAPARAK). In this platform, the interchange fee is the primary dependent variable for the model of issuing the payment cards, and the other variables are the control variables. Thus, the general form of the model of issuing card payment in Iran can be the following panel model:

$I S U R_{i t}=\alpha I F_{i t}+\beta X_{i t}+u_{i t}$

Based on the information of the CBI and SHAPARAK, the payment card network in Iran works with multi-homing. More specifically, 29 banks issue payment cards, and each cardholder has payment cards from many banks. Thus, the ratio of issuing payment cards (ISUR) by each issuer bank between all active banks is a function that depends on: 
1) Interchange fee (IF): Because issuer banks receive fees from acquirer banks to reach card transactions, this variable has a positive effect on issuing payment cards.

2) Network externality (NE): The number of merchants who have adopted a POS terminal in the market where the cardholder operates is affected by the payment cards that cardholders receive from issuer banks. Thus, this variable has a positive effect on issuing payment cards.

3) Platform fixe cost: Issuer bank should pay to the payment network platform $\left(\mathrm{C}_{\mathrm{I}}\right)$. In Iran, the payment system issuer banks should pay a fixed cost to SHAPARAK and SHETAB system. This variable negatively affects issuing payment cards.

4) Bank size (S): Bigger banks have more clients and issue more cards.

5) The interest of the loans: This interest is the fee issuer banks receive from the clients (IL) that get loans from the banks. Generally, most banks open accounts for his clients for gathering money as deposits and provide this money to the borrower (i.e., persons that borrow money from the bank and pay the interest rate). Issuing payment card can then be expressed as:

$$
I S U R=\alpha_{0}+\alpha_{1} I F+\alpha_{2} C_{I}+\alpha_{3} N E+\alpha_{4} S+\alpha_{5} I L+u_{i}
$$

where $\alpha 1$ is the interchange fee effects that issuer banks receive from acquirer banks, $\alpha 2$ is the effect of fixed cost that issuer bank should pay to the platform. $\alpha 3$ is the effect of network externality, $\alpha 4$ is the effect of bank size, $\alpha 5$ is the effect of interest of loans that issuer bank provided to the borrower, and ui is a mean-zero error term of the model.

\subsection{The Variables}

Independent variable (Issuing card ratio-ISUR): In the payment card network, issuing cards is one side of the market that is related to many variables. According to the theory of the two-sided market, literature review, and Iranian payment situation with 29 banks, the monthly issuing payment card ratio for each bank is the independent variable. This variable is the ratio of issued payment cards by each bank in each month to total payment cards of the Iran payment system at that month.

Dependent variable (Interchange fee- $I F$ ): The fee that should be paid by acquirer banks to issuer banks is $1 \%$ of the value of each payment. The minimum and maximum fees are $500 \mathrm{Rls}$ and $2500 \mathrm{Rls}$, respectively.

Control Variables: Four control variables are as follows: 
- Interchange fee (IF): It is the fee that each acquirer bank should pay to the issuer bank for each payment. This fee is $1 \%$ of the value of each transaction (a minimum of $500 \mathrm{Rls}$ and a maximum of $2500 \mathrm{Rls}$ ). The unit of this variable is Rls.

- Platform Cost (CI): It is a fixed cost paid by the issuer bank to the payment network. For each transaction, the issuer bank should pay $250 \mathrm{Rls}$ to SHAPARAK and $250 \mathrm{Rls}$ to the SHETAB system.

- Network Externality (NE): This parameter, expressed in percentage (\%), denotes the effects of the number of cards on merchants for accepting POS for selling transactions. SHAPARAK provides this information as an acquiring ratio.

- Size (S): The size of banks is the ratio of ATM to total ATM of 29 banks in Iran (unit is the percent).

- The interest of Loans (IL): Banks use a part of their client's deposits to lend for borrowers. This variable is calculated by $18 \%$ as the interest rate for bank loans according to CBI information (Unit is Rls).

\section{The Results}

\subsection{Descriptive Statistics}

The descriptive statistics of each variable were calculated separately. Table 1 represents the descriptive statistics of the analyzed variables for 29 governments, private, and professional banks accepted by Iran Central Bank. Data are monthly from March 2016 to August 2016. In some variables such as ISUR, NE, S, and IL, mean and standard deviation are low and near to each other. The reason is that these variables are generally according to the structure of activities of the banks defined by the Central Bank and can vary in a limited range. Mean and standard deviation of IF and CI are high because the activity, number of branches, and strategy of each bank can affect the range of these variables. Some banks are more active and attract more clients then they receive, have a higher role in card transactions, and should pay a more fixed cost per each transaction to SHAPARAK and SHETAB.

The results of this study show positive feedback between ISUR and IF, as theory said (Fig. 2). It means that issuing cards can make revenue to issuer banks because for each card transaction, acquirer banks should pay interchange fees (IF) to issuer banks. Also, paying the fixed cost to SHAPARAK and SHETAB for each transaction has an inverse relation with ISUR that justifies the theory (Fig. 3). Another important variable in the Iran 
payment card system is network externality (NE), which has a positive relation with ISSUR. It means that accepting POS by acquiring banks on one side has positive effects on the issuing side of the market.

Table 1

Descriptive statistics of model variables

\begin{tabular}{cccccc}
\hline Variable & Obs. & Mean & Std. Dev. & Min & Max \\
\hline ISUR & 1,218 & 3.5801 & 4.9328 & .01 & 23.25 \\
IF & 1,218 & 11.657 & 18.437 & .0494 & 137.143 \\
CI & 1,218 & 44.366 & 96.711 & 1.0767 & 1043.69 \\
NE & 1,218 & 3.2613 & 5.3050 & .01 & 31.9 \\
S & 1,218 & 3.4848 & 4.1348 & .06 & 45 \\
IL & 1,218 & .723235 & .187582 & .50216 & 1.06063 \\
\hline
\end{tabular}

Source: Research finding

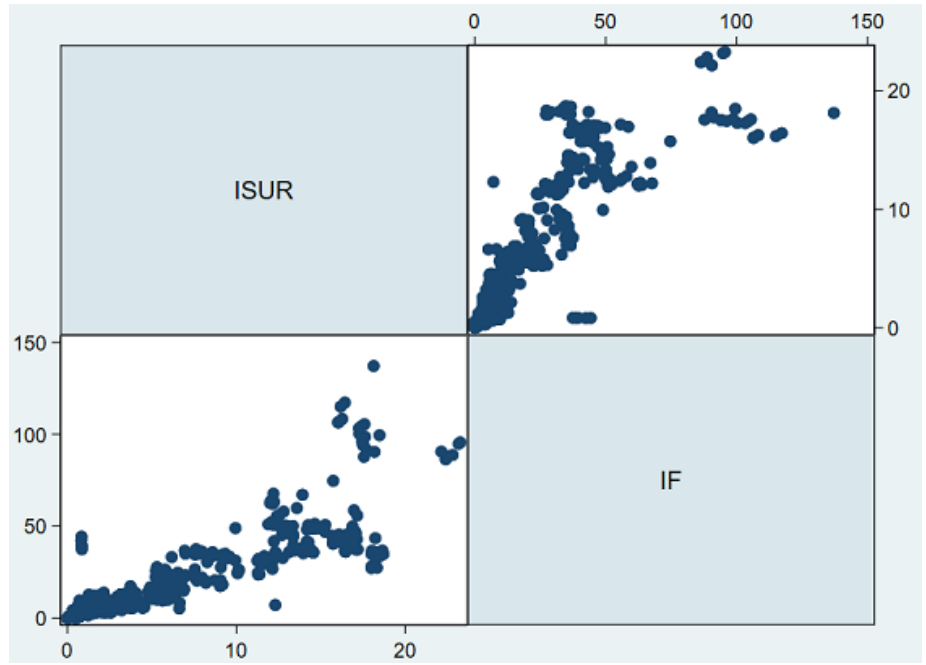

Figure 2. Positive relation between ISUR and IF 


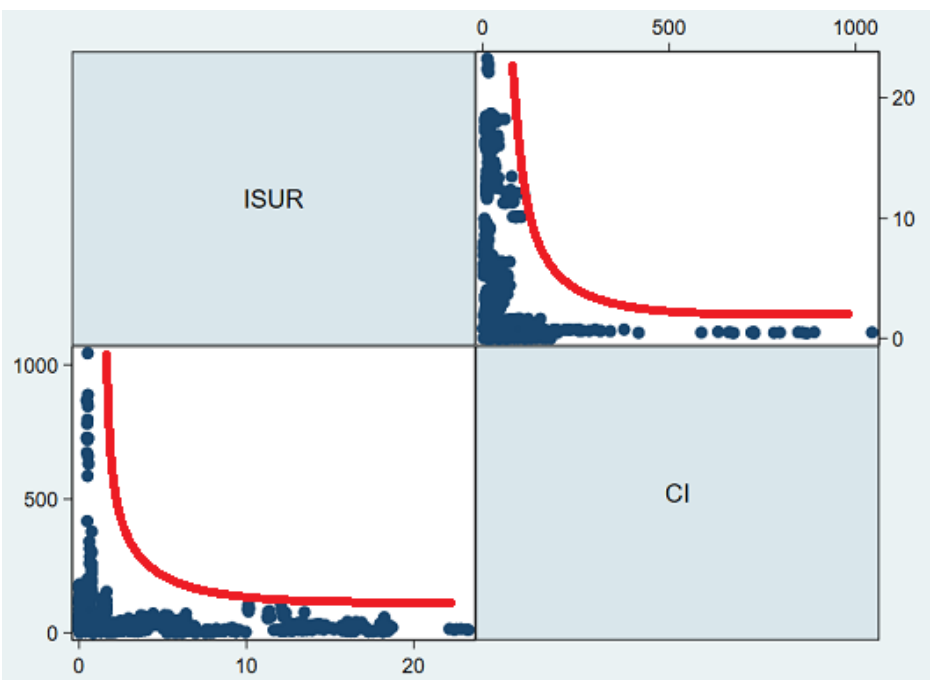

Figure 3. Inverse relation between ISUR and SHAPARAK and SHETAB fixed cost (Platform cost)

\subsection{Unit Root Test Results}

Before modeling in research, to prevent pseudo-regression, first, the stationarity of variables was investigated using Levin, Lin, and Chu's test (LLC). According to the results of unit root test in Table 2, the "prob" value reported for all research variables is less than 0.05 , the null hypothesis (suggesting the existence of unit root) is rejected at 95\% significant level. Consequently, all variables are at a stationary level and accumulated zero order.

Table2

Unit Root Test Results of the research

\begin{tabular}{llc}
\hline & Variables & Levin, Lin, and Chu (LLC) test \\
\cline { 2 - 3 } & Statistic & Prob. \\
ISUR & -2.335 & .0098 \\
IF & -9.536 & .0000 \\
C $_{\mathrm{I}}$ & -7.621 & .0000 \\
NE & -14.464 & .0000 \\
S & -4.290 & .0000 \\
IL & -4.146 & .0000 \\
\hline
\end{tabular}

Source: Research Findings. 


\subsection{F- Leamer Test and Estimating the Fixed Effects Model}

First, it is required to provide the needed statistical tests to determine the type of model. The Leamer test results for the research model are represented in Table 3. The probability value of this test is more than $5 \%$ for the research model. Thus, the null hypothesis is accepted, and the model is the panel, not pooling.

Table 3

Leamer Test Results

\begin{tabular}{llll}
\hline Type of Test & Test Statistic & Prob. & Result \\
\hline Leamer & 96.85 & .0000 & $\begin{array}{l}\text { Confirmation of } \mathrm{H}_{0} \text { and rejecting pooling } \\
\text { model }\end{array}$ \\
\hline
\end{tabular}

Source: Research finding

\subsection{Breusch and Pagan Test (Random Effects Test)}

First, model 23 estimated using the variables and for testing the random effect hypothesis used from Breusch and Pagan test. According to this test, we can reject the random effect hypothesis because the test statistic is 2520.66 at a critical level, and thus the model has fixed effects. Accordingly, we should estimate the fixed-effects model. The results of the random effects tests are provided in Table 4. Moreover, according to the literature point, due to some fixed features of the Iranian banks resulted from the Central Bank rules, the fixed effects model is suitable for this study. 
Table 4

Breusch-Pagan Test Results

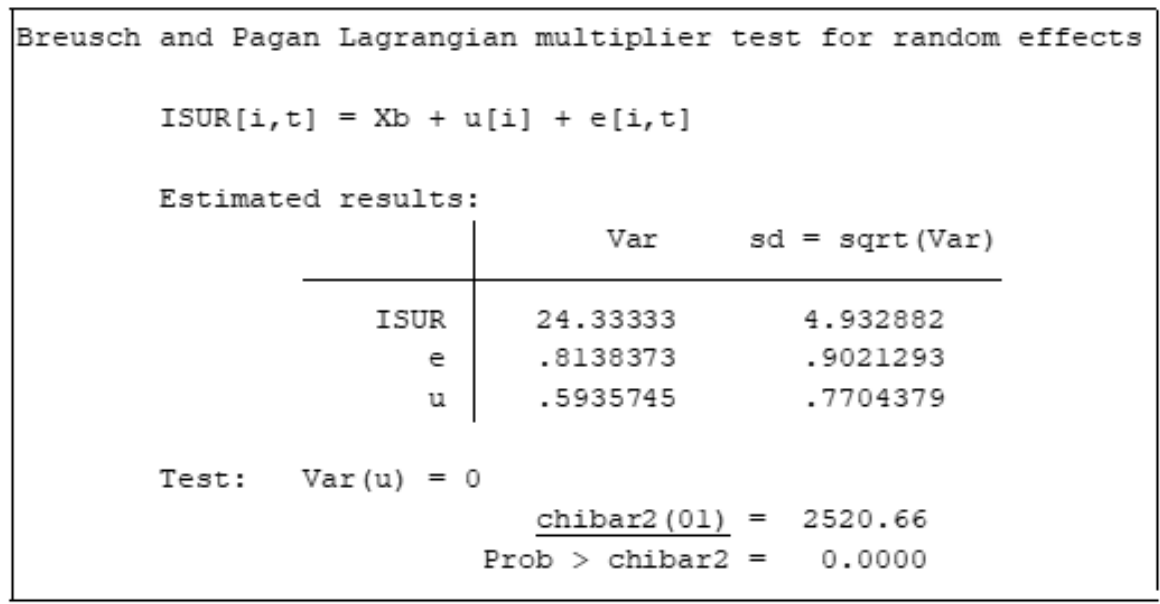

Source: Research finding

\subsection{Results of Estimating the Model}

Estimates of model 23 as a fixed-effects panel model are provided in Table 5. This estimation is for 29 banks as cross-sections and 1218 observations in the period of the model (March 2016 to August 2019).

Table 5

Results of Estimating the Model

\begin{tabular}{lllll}
\hline Variable & Estimated Coefficient & Std. Error & t-Statistic & $\mathbf{P}>|\mathbf{t}|$ \\
\hline Intercept & .675933 & .182 & 3.71 & .000 \\
IF & .030318 & .00344 & 8.79 & .000 \\
CI & -.001181 & .00038 & -3.1 & .002 \\
NE & .479080 & .0339 & 14.1 & .000 \\
S & .000552 & .0204 & .03 & .978 \\
IL & 1.43630 & .481 & 9.7 & .000 \\
Overall R2 & 59.9 & & & \\
Between R2 & 61.7 & & & \\
F & 69.5 & & & \\
\hline
\end{tabular}

Source: Research finding

As can be seen from Table 5, the significance of the total fixed effects regression model is confirmed considering the statistic $\mathrm{F}$ at the confidence 
level of $95 \%$. The estimation shows that there is a significant difference in issuing payment cards by the banks (cross-sections) in the period of the estimation. Also, the value of the overall $\mathrm{R}^{2}$ shows that $59.9 \%$ of changes are explained by the independent and control variables. Furthermore, $\mathrm{R}^{2}$ between groups is $61.7 \%$ and shows that the changes in the payment card issuing are explained by the independent and control variable in each group.

\section{Conclusions and Discussions}

The main aim of this paper is to analyze the card payments system regulation and investigating the effect of the model variables on issuing the ratio of payment cards in the Iranian banking system for 29 banks. The main points extracted on the impact of the above variables on the issuing payment cards are as follows:

1) The interchange fee is revenue for issuing banks. According to estimation results, this variable is significant and theoretically has a positive effect on issuing payment cards with a coefficient of 0.030318 . For 100,000 Rls., interchange fee that issuer banks receive from acquirer banks, the issuing ratio of payment card will increase by 3032 . Thus, regulating IF can balance two sides of the market with attention to network externality.

2) Fix cost that issuer banks should pay to the platform (CI) is the cost of issuing banks. According to estimation results, this variable is significant with adverse effects on issuing payment cards (according to theory), and the coefficient is -0.001181 . For 100,000 Rls. of this cost that issuer banks should pay for transactions, the issuing ratio of payment cards will decrease by 118 .

3) The effect of bank size (S) on issuing ratio of payment cards according to estimation result is not significant.

4) Network externality (NE), which is the accepting POS by acquirer banks due to issuing payment cards by issuer banks, is significant with positive effects (according to theory). The values obtained for this coefficient is 0.479080 , suggesting that for a $1 \%$ increase in network externality, the issuing ratio of payment cards will increase by 0.479 .

5) The Iranian banking system provides payment cards for each new account open by clients. After subtracting bank reserves (held in Central Bank), banks can provide deposits of his clients to borrowers and receive interest rates. In Iran, this rate is $18 \%$ yearly. Thus, variable IL that shows the average interest rate of bank loans per bankcard according to estimation result is statistically significant. Overall, it has a positive effect on issuing a payment card. This estimated coefficient is 1.4363 . 
6) In general, the results of estimating the model and examining the effects of the mentioned variables show that the card payments system should be regulated.

Iran's card payments system is monopolistic, and SHAPARAK is the sole platform under the rules of the Central Bank that provides payment services to 29 banks in Iran. Iranian banks mainly provide debit cards, and the share of credit cards in all kinds of payment cards is less than $1 \%$. The 29 Iranian banks provide ATM services, POS, internet banks, and Mobile bank services to the clients. However, our results indicate that raising deposits, issuing loans, and collecting interest income are the primary goals of Iranian banks. The evidence of this matter is the coefficient of the interest rate at the model (IL coefficient) that is bigger than the coefficients of other variables such as IF, $\mathrm{C}_{\mathrm{I}}$, and NE.

The 29 banks not only are card issuer but also are active acquirers. The cardholders (buyers) do not pay any fee to issuer banks, and merchants (sellers) do not pay merchant fees to acquirer banks. According to the Central Bank and SHAPARAK rules, the issuer banks should pay $250 \mathrm{Rls}$ to SHAPARAK and $250 \mathrm{Rls}$ to SHETAB system for each card transaction as platform fixed costs $\left(\mathrm{C}_{\mathrm{I}}\right)$.

The results of the estimation of issuing ratio of payment cards model in this paper show that the issuer banks receive an interchange fee (IF) from acquirer banks and pay fixed costs to the platform. The banks provide payment services without any cost to cardholders and merchants. Also, they receive an interest rate of loans at a rate of $18 \%$ (or more) for compensating the costs of payment services, leading to an increase in the cost of bank loans for clients.

Hence, for balancing the two sides of the market (cardholders and merchants) in the Iran payment network of cards, the antitrust organization should intervene in this process for decreasing the interchange fee (IF) and fixed cost of the platform $\left(\mathrm{C}_{\mathrm{I}}\right)$ for decreasing the interest rate of bank loans. This activity can improve the financing of economic activities and reduce the costs of issuer and acquirer banks. Finally, this intervention can improve the payment card network activity for increasing the use of bankcards in payments. In this way, the card payments system in Iran must be regulated by related organizations.

\section{References}

Armstrong, M. (2006). Competition in Two-Sided Markets. RAND Journal of Economics, 37(3), 668-691. 
Ausubel, L. (1991). The Failure of Competition in the Credit Card Market. American Economic Review, 81(1), 50-81.

Baxter, W. F. (1983). Bank Interchange of Transactional Paper: Legal and Economic Perspectives. Journal of Law and Economics, 26, 541-588.

Brito, D., \& Hartley, P. R. (1995). Consumer Rationality and Credit Cards. Journal of Political Economy, 103:4, 400-433.

Caillaud, B., \& Jullien, B. (2003). Chicken \& Egg: Competition among Intermediation Service Providers. RAND Journal of Economics, 34(2), 309-28.

Carbó-Valverde, S., Humphrey, D. B., Liñares-Zegarra, J. M., \& RodríguezFernandez, F. (2009). A Cost-Benefit Analysis of a Two-Sided Card Market. Moneda Crédito, 227, 7-36.

Chakravorti, S., \& To, T. (2000). Towards a Theory of Merchant Credit Card Acceptance, mimeo, Federal Reserve Bank of Chicago. Working paper.

Chakravorti, S. (2003). Theory of Credit Card Networks: A Survey of the Literature. Review of Network Economics, 2(2), 50-68.

European Commission (2007). Antitrust: Commission Prohibits MasterCard's intraEEA Multilateral Interchange Fees. IP/07/1959. Brussels.

Gowrisankaran, G., \& Stavins, J. (2004). Network Externalities and Technology Adoption: Lessons from Electronic Payments. The RAND Journal of Economics, Vol. 35, No. 2, 260-276.

Humphrey, D., \& Berger, A. (1990). Market Failure and Resource Use: Economic Incentives to Use Different Payment Instruments. In: Humphrey, D. (Ed.), The US Payments System: Efficiency, risk, and the Role of the Federal Reserve. Kluwer Academic Publishing, Norwell, MA: 45-86.

Humphrey, D., \& Pulley, L. (1997). Bank's Responses to Deregulation: Profits, Technology and Efficiency. Journal of Money, Credit and Banking, 29, 73-93.

Hunt, R. (2003). An Introduction to the Economics of Payment Card Networks. The Review of Network Economics, 2:2, 80-96.

Kaiser, U., \& Wright, J. (2006). Price Structure in Two-Sided Markets: Evidence from the Magazine Industry. International Journal of Industrial Organization, Elsevier, 24(1), 1-28.

Katz, M. L. (2001). Reform of Credit Card Schemes in Australia II: Commissioned Report, Reserve Bank of Australia. Workingpapers.

Knittel, C., \& Stango V. (2003). Price Ceilings as Focal Points for Tacit Collusion: EvidencefromCreditCards. American Economic Review, 93:5, 1703-29.

Prager, R. A., Manuszak, M. D., Kiser, E. K., \& Borzekowski, R. (2009). Interchange Fees and Payment Card Networks: Economics, Industry Developments, and Policy Issues. Staff working papers in the Finance and Economics Discussion Series (FEDS) 2009-23.

Rochet, J. C., \& Tirole, J. (2002). Cooperation among Competitors: Some Economics of Payment Card Associations. RAND Journal of Economics, 33, 1-22.

Rochet, J., \& Tirole, J. (2003). Platform Competition in Two-Sided Markets. Journal of European Economic Association, 1, 990-1029. 
Rochet, J., \& Tirole, J. (2004). Two-Sided Markets: An Overview, mimeo, IDEI University of Toulouse. Working papers.

Rochet, J., \& Tirole, J. (2005). Two-Sided Markets: A Progress Report, mimeo, IDEI University of Toulouse. Working papers.

Schmalensee, R. (2002). Payment Systems and Interchange Fees. Journal of Industrial Economics, 50, 103-122.

Wright, J. (2004). The Determinants of Optimal Interchange Fees in Payment Systems. Journal of Industrial Economics, Volume LII, 1-26.

Wright, J. (2005). Why Do Firms Accept Credit Cards? mimeo. The University of Auckland. Working paper 